\title{
Chemical Compositions and Resistant Starch Content in Starchy Foods
}

\author{
Anuchita Moongngarm \\ Department of Food Technology and Nutrition, \\ Faculty of Technology, Mahasarakham University, Mahasarakham, Thailand
}

Received 2012-08-22, Revised 2012-09-24; Accepted 2013-03-28

\begin{abstract}
Resistant Starch (RS) is one of nature's most interesting bioactive compounds. There is a wide variety of starchy food plants in Thailand that are good sources of RS, but they have not been well studied. As such, this study was carried out to investigate the potential food source of RS. Twenty-two promising food plants were selected. The samples included (1) cereals comprised of five long grain rice of $O$. sativa L. and sweet corn, (2) six species of root and tuber crops, (3) green banana fruits (Musa sapientum L.) composed of ABB group, AAB group and AAA group at the first stage of ripening and (4) legume seeds included cowpea seeds ( 3 different cultivars), red bean, red kidney bean and mung bean. All food plants were determined for chemical compositions, resistant starch, non-resistant starch, total starch and amylose content. The study found that the starchy foods varied in their chemical compositions. The major composition of all foods was carbohydrate ranging between 58.19 (in black speck cow pea) and 87.21\% (in cassava root), whilst the fat, ash and fiber were observed only in small quantities. The protein content was highest in legume seeds (20.78 to $27.22 \%$ ). For the study on starch compositions, green bananas contained highest amount of resistant starch ranging between 35.14 and $45.87 \%$, indicating that more than a half of total starch in banana RS content varying from 35.14 to $45.87 \%$, whereas the RS content of legumes ranging from 2.33 to $10.63 \%$ and 1.16 to $4.85 \%$ in cereal grains. Most of the starchy food plants contained moderate to high level of amylose (11.45-34.85\%), except the waxy rice $(2.72 \%)$.
\end{abstract}

Keywords: Resistant Starch, Green Banana, Total Starch, Rice, Roots and Tubers

\section{INTRODUCTION}

Functional foods are foods that provide health benefits beyond basic nutrition. They typically contain certain physiologically active components which may or may not have been manipulated or modified to enhance their bioactivity. These foods may help prevent disease, reduce the risk of developing disease, or enhance health (Hasler and Brown, 2009). Recently, as consumers have become increasingly interested in achieving and maintaining their good health, attention to functional foods has increased. Resistant Starch (RS) is among the bioactive compounds attracting consumer's interest, especially, those at risk of diabetes and other related diseases. RS, by definition, is a fraction of the starch that is not broken down by enzymes in the small intestine. It then enters the large intestine where it becomes the substrate for bacterial fermentation producing short chain fatty acids (Elmsthl, 2002). RS resists digestion and passes through to the large intestine where it acts like dietary fiber. RS can be categorized into four types (Nugent, 2005): RS type1 (RS1) a physically inaccessible resistant starch, found in whole or partially intact seeds, legumes and unprocessed whole grains. RS type 2 (RS2) occurs in the ungelatinized, native granular form and is usually found in unripe bananas, high amylose corn and raw potatoes. Due to the high degree of crystallinity, RS2 is less susceptible to hydrolysis. RS type 3 (RS3) is formed when starch is moist, heated and cooled. The process of heating the starch and cooling it is called retrogradation. RS type 4 (RS4) is chemically modified to resist degradation by digestive enzymes. This type of resistant starch can have a wide variety of structures and is not found in nature (Fuentes-Zaragoza et al., 2010; AparicioSaguilan et al., 2007; Sanz et al., 2009). 
There are a variety of food sources containing RS; however, limited data are available in food science literature on RS content in food plants popularly consumed in Thailand. Rice (Oryza sativa L.) is considered as a main staple food, not only for the population of Asia, but for the populations of other countries the world over. It is a major energy food source that is consumed daily. There are a number of rice varieties grown in Thailand. Rice types, based on amylose content, varying from $0-35 \%$, can be classified into 4 groups composed of waxy, low amylose, moderate amylose and high amylose rice. Each varies in their chemical compositions, properties and qualities.

Green (unripe) banana flour is a good source of resistant starch. In several studies, the physiological importance of RS in bananas has been investigated mainly with regard to glycemic index, cholesterol lowering capability and colonic effects. Moreover, major bioactive compounds, including polyphenols, ascorbic acid and carotenoids, demonstrate strong protective effects against degenerative diseases such as cancer and cardiovascular disease (Ovando-Martinez et al., 2009; Wang et al., 2012) Musa sapientum Linn., is a banana type popularly grown in all regions of Thailand. However, the chemical compositions and RS content in the green bananas differed from those in previous studies. The differences were attributed to varieties of banana species, banana ripening stages, as well as the methods used in the starch analysis.

Legumes are recognized as an economical source of calories and proteins, particularly for developing countries since their seeds contain high concentration of carbohydrates (50-67\%) and protein (23-25\%) (Olapade et al., 2012). Cowpeas and beans vary in shape and color and also contain a large variation of resistant starch. Similarly to other starchy food plants, roots and tubers are good sources of starch. However, in Thailand, RS content of cowpea seeds, roots and tubers has not yet gained much attention.

Moreover, the significance of the chemical compositions and RS content of several food plants is still arguable, mostly due to the variations in cultivars, climate, post-harvest management and food processes applied in different countries. Therefore, the present study was carried out to investigate the chemical compositions, RS content and starch compositions in starchy food plants.

\section{MATERIALS AND METHODS}

\subsection{Sample Collection}

Twenty-two well recognized common food plants in Thailand were selected. The samples consisted of four groups of plants including cereals, roots and tubers, green banana fruits and legume seeds. Paddy rice samples were purchased from the local milling factory; whereas, other samples were purchased from a local market in Mahasarakham province, Thailand. Cereal crops included four long grain milled rice of $O$. sativa $\mathrm{L}$. (Waxy rice (RD6), Lueng 11, Khao Dok Mali 105 (KDML 105) and Khao Ta Hang), one long grain brown rice (Khao Dok Mali 105) and sweet corn (Zea mays). Roots and tubers included yam bean (Pachyrhizus erosus), sweet potato (white; Ipomoea batatas) white yam (round tuber; Dioscorea alata), lesser yam (Dioscorea alata), cassava root (Manihot esculenta) and taro (Colocasia esculenta). The legume seeds included cowpeas (Vigna unguiculata) (three different cultivars; black, white, black/white speckled seed colors), red bean (Vigna angularis), red kidney beans (Phaseolus vulgaris) and mung bean (Vigna radiata). Green banana fruits (Musa sapientum Linn) comprised of ABB group (Kluai Namwa), AAB group, (Kluai Khai) and AAA group (Kluai Hom) at the first stage of ripening (105-120 days from bunch emergence).

\subsection{Sample Preparation}

Paddy rice samples were dehulled, ground and passed through a sieve ( $40 \mathrm{~mm}$ mesh size). Sweet corn was shelled and freeze dried and the dried corn kernels were finely ground and sieved. The root and tuber samples were washed and cleaned with tap water, blotted and peeled to remove the inedible portion prior to cutting them into small pieces. They were then freeze dried and ground using a coffee grinder. Green banana preparation involved peeling banana fruits and cutting them into $2.0 \mathrm{~mm}$ slices and immediately dipping them into a citric acid solution $(0.3 \% \mathrm{w} / \mathrm{w})$ for $10 \mathrm{~min}$ in order to reduce enzymatic browning. The slices were dried at $50^{\circ} \mathrm{C}$ in a tray dryer until the final moisture content was approximately $8 \%$. They were then ground and passed through a 40-mesh sieve to obtain banana flour. For legume seed preparation, the whole seeds were traydried at $50^{\circ} \mathrm{C}$ to obtain approximately $8 \%$ of moisture content. They were then finely ground and passed through a sieve. The ground samples were packed in plastic bags and stored in a refrigerator until use.

\subsection{Chemical Composition Analysis}

The chemical compositions were determined by standard methods of the Williams (1984); moisture by drying in an oven at $105^{\circ} \mathrm{C}$ until constant weight; ash content by incineration in a muffle furnace at $550^{\circ} \mathrm{C}$; crude protein by micro-Kjeldahl, using 5.95 as the nitrogen to protein conversion factor for cereals and using 6.25 for other samples; crude fat by the Soxhlet 
extraction method with petroleum ether as solvent, crude fiber by acid-base digestion. Available carbohydrate content was calculated by difference, $(100-(\%$ protein + $\%$ fat $+\%$ moisture $+\%$ protein).

\subsection{Determination of Resistant Starch, Non- Resistant Starch and Total Starch}

The contents of RS, non-resistant starch and total starch were analyzed using the Megazyme resistant starch assay kit (Megazyme International Ireland Ltd, Bray, Ireland).

In summary, $100 \pm 5 \mathrm{mg}$ of the sample was weighed individually into screw cap tube, added with $4.0 \mathrm{~mL}$ of pancreatic $\alpha$-amylase solution $\left(10 \mathrm{mg} \mathrm{mL}^{-1}\right)$ containing amyloglucosidase (AMG) $\left(3 \mathrm{U} \mathrm{mL}^{-1}\right)$ and subsequently incubated at $37^{\circ} \mathrm{C}$ with continuous shaking (200 strokes $/ \mathrm{min}$ ) for exactly $16 \mathrm{hr}$. To aid dispersion, $4.0 \mathrm{~mL}$ of $99 \%$ Industrial Methylated Spirits (IMS) was added to the tube with vigorous stirring and then centrifuged at $1,500 \mathrm{~g}$ for $10 \mathrm{~min}$. The supernatants were drawn and kept for digestible starch analysis. The pellets were resuspended in $2 \mathrm{~mL}$ of $50 \%$ IMS, washed with $6 \mathrm{~mL}$. The pellet was kept for resistant starch determination whereas the centrifuged washings were combined with the original decanted supernatant and used for solubilized starch determination.

\subsection{Determination of Resistant Starch}

The pellets was resuspended with $2 \mathrm{~mL}$ of $2 \mathrm{M}$ $\mathrm{KOH}$. After continuously stirring for $20 \mathrm{~min}$ in an ice bath, $8 \mathrm{~mL}$ of $1.2 \mathrm{M}$ sodium acetate buffer $(\mathrm{pH} \mathrm{3.8)}$ and $0.1 \mathrm{~mL}$ of AMG $\left(3300 \mathrm{U} \mathrm{mL}^{-1}\right)$ were added and the tubes were placed in a water bath at $50^{\circ} \mathrm{C}$ for $30 \mathrm{~min}$. At the end of the treatment, the solution was brought to a total volume of $100 \mathrm{~mL}$ with distilled water, mixed and centrifuged at $1,500 \mathrm{~g}$ for $10 \mathrm{~min}$. A $0.1 \mathrm{~mL}$ aliquot of supernatants was treated with $3.0 \mathrm{~mL}$ of D-glucose (oxidase-peroxidase) assay kit (GOPOD) reagent (Megazyme, Ireland), vortex-mixed and kept at $50^{\circ} \mathrm{C}$ for 20 min. Blank $(0.1 \mathrm{~mL}$ of $100 \mathrm{mM}$ sodium acetate buffer $\mathrm{pH} 4.5$ ) and $3.0 \mathrm{~mL}$ of GOPOD and glucose standards $0.1 \mathrm{~mL}$ of D-glucose $\left(1 \mathrm{mg} \mathrm{mL}^{-1}\right)$ and $3.0 \mathrm{~mL}$ of GOPOD, were incubated concurrently. The absorbance was read with a spectrophotometer at 510 $\mathrm{nm}$. The total starch contents were calculated as the sum of digestible starch and resistant starch.

\subsection{Determination of Digestible Starch or Solubilized Starch (Non-Resistant Starch)}

The supernatants from centrifugation were adjusted to $100 \mathrm{~mL}$ with $100 \mathrm{mM}$ sodium acetate buffer $(\mathrm{pH} 4.5)$. The resulting aliquots $(0.1 \mathrm{~mL})$ were incubated with $10 \mu \mathrm{L}$ of dilute AMG solution $\left(300 \mathrm{U} \mathrm{mL}^{-1}\right)$ in $100 \mathrm{mM}$ sodium maleate buffer ( $\mathrm{pH} 6.0$ ) for $20 \mathrm{~min}$ at $50^{\circ} \mathrm{C}$ and followed by second incubation with $3.0 \mathrm{~mL}$ of glucose oxidase plus peroxidase (GOPOD) reagent for a further $20 \mathrm{~min}$ at $50^{\circ} \mathrm{C}$. The absorbance was measured at $510 \mathrm{~nm}$ against a reagent blank. The absorbance was used in the calculation of solubilized starch content. The total starch content of the tested samples was calculated as the sum of the resistant starch and solubilized starch fractions.

\subsection{Amylose Content}

Apparent amylose content was determined after iodine complexation according to the method of Morrison and Laignelet (1983).

\subsection{Statistical Analysis}

All samples were analyzed in triplicates and data were expressed as means and standard deviations. Data obtained were subjected to statistical Analysis of Variance (ANOVA) using SPSS for Windows. The difference in means was determined by Duncan Multiple Range Test (DMRT). Statistical significance was set at $95 \%$ confidence level.

\section{RESULTS}

\subsection{Chemical Compositions}

The major chemical compositions of all food plants are listed in Table 1. Generally, the major composition of all starchy foods in this study was carbohydrate with the mean values ranging from $58.19 \%$, in black and white speck cow pea, to $87.21 \%$ in cassava root. The cereal samples had average moisture content varying between 7.94 and $9.44 \%$. These values were lower than the limit value of $14 \%$, the recommendation for safe storage of processed rice (Howell and Cogburn, 2004). The The protein contents differed from 6.78 to $8.87 \%$ in rice, showing the higher value in brown rice than milled rice, while the highest value was found in sweet corn $(11.36 \%)$. The rice cultivars and types also affected crude fat content. The milled rice of Lueng 11 and KDML 105 had lowest amount, ranging from 1.27 to $1.46 \%$, respectively, whereas the fat content of RD6 (waxy rice) and Khao Ta hang varied from $1.79 \%$ to $1.85 \%$. The brown rice of KDML 105 had higher level of crude fat $(2.92 \%)$ than that milled rice of KDML 105 and also other milled rice samples. In the cereal group, sweet corn indicated the highest concentration of fat $(5.47 \%)$. For ash content, milled samples did not differ significantly among themselves having the mean values between 1.22 and $1.51 \%$, which was lower than the brown rice $(2.12 \%)$ and corn kernel $(2.36 \%)$. Milled rice samples had means of crude fiber varying from 0.40 to $0.88 \%$, whereas corn had the highest values $(8.49 \%)$. 
The chemical compositions of roots and tubers are also presented in Table 1. The moisture contents of all samples ranged from 7.44 to $9.10 \%$. The moisture content of yam bean $(9.10 \%)$, taro $(8.81 \%)$ and sweet potato $(8.42 \%)$ was significantly higher than that observed in lesser yam $(7.44 \%)$, white yam $(7.67 \%)$ and cassava root $(7.61 \%)$. The protein content was significantly highest in the lesser yam (10.94\%), whilst the lowest values were observed in yam bean and cassava root $(1.23 \%$ and $1.50 \%$, respectively). The crude fat content in roots and tubers presented only a small quantity in sweet potato, lesser yam, white yam, taro and cassava, varying from 0.14 to $0.48 \%$, whereas the highest level was found in yam bean $(1.17 \%)$. The mean values of ash content of roots and tubers varied between 1.24 and $3.14 \%$. The highest values were found in sweet potato, white yam and taro. For the crude fiber content, yam bean was predominate with the level of $10.94 \%$, whilst the crude fiber content in the remaining samples ranged from 1.33 to $2.25 \%$. Basically, roots and tubers in the present study contained a high amount of carbohydrate, similar to that of cereal foods, ranging between 79.30 and $87.21 \%$, except in yam bean $(76.32 \%)$. The chemical compositions of green bananas were shown in Table 1. They were observed that green bananas were good sources of ash (3.67-4.61\%) and fiber (5.11-8.82\%). They were also found that banana cultivars affected the chemical contents. Musa ABB group banana (Kluai Nam Wa) contained the highest amount of crude fiber, whereas the Musa AAA group (Kluai Hom) had the highest level of available carbohydrates.

Table 1 indicates the chemical constituents of whole seed cowpeas, red bean, red kidney bean and mung bean. In general, the compositions of cowpea seeds were close to those of red bean and red kidney bean, except in the mung bean. The protein contents of legumes varied from 20.78 to $27.22 \%$. The greatest value was detected in the black/white speckled cowpea $(27.22 \%)$, followed by mung bean $(24.08 \%)$, red kidney bean $(23.83 \%)$, white cowpea $(22.34 \%)$ and black cowpea $(20.78 \%)$. For the crude fat contents, the highest value was observed in white cowpea $(2.08 \%)$ and the lowest content was found in red bean $(0.63 \%)$, whereas the contents in other legumes varied from 1.36 to $1.55 \%$. The contents of ash in all legumes were comparable ranging from 3.85 to $4.23 \%$, except for the mung bean $(2.87 \%)$. The highest contents of crude fiber were detected in mung bean $(2.20 \%)$ and white cowpea $(1.88 \%)$, whereas the red bean indicated the lowest content $(1.39 \%)$. The carbohydrate content of legumes varied from 58.19 to $64.26 \%$. The black cowpea and red bean showed the highest content (64.26 and $62.29 \%$, respectively) whilst the lowest content was observed in the black/white speckled cowpea $(58.19 \%)$.

\subsection{Starch Compositions}

The starch compositions of each starchy food type are presented in Table 2, showing RS, non-RS, total starch and amylose content. The RS concentration of the cereals in this study was low and varied from 1.16 to $4.85 \%$. The results of RS content in rice implied that cultivars containing high amylose content, Lueng 11 and Khao Ta Hang, had higher RS level (4.41 and 4.85\%, respectively) than low amylose rice (waxy and KDML 105). In contrast, non-resistant starch and total starch contents were higher in the low amylose rice than the high amylose rice. The total starch contents of rice varied from 68.57 to $74.76 \%$, whilst the total starch in sweet corn was only $36.23 \%$. For the amylose content, the waxy rice contained the lowest amount of amylose $(2.13 \%)$ whereas the highest content was found in Lueng11 (29.67\%).

The RS contents of roots and tubers differed significantly (Table 2). The highest amount was observed in the lesser yam $(23.25 \%)$ followed by cassava root $(9.69 \%)$, whereas those in the white yam, yam bean and taro were comparable ranging between 3.69 and $4.30 \%$. The lowest RS content was found in sweet potato (3.19\%). Non-resistant starch of lesser yam and yam bean were lowest, 19.46 and $20.27 \%$, respectively, whilst the non resistant starch in the remaining roots and tubers varied from $49.35 \%$ (sweet potato) to $59.61 \%$ (taro). The lowest total starch content was found in yam bean $(23.96 \%)$, whereas the other roots and tuber were found between 52.54 and $65.70 \%$. The total amylose content was low in the yam bean samples $(11.45 \%)$, while white yam and taro contained moderate concentrations (17.32 and $16.84 \%$ respectively). The highest levels of amylose were found in lesser yam and sweet potato (26.20 and $28.05 \%$, respectively.

The starch compositions of green banana are indicated in Table 2. The results showed that green banana samples were good sources of RS, ranging between 35.14 and $45.87 \%$, while the non-resistant starch varied from 19.38 to $31.99 \%$. Total starch contents were $62.77,66.90$ and $67.45 \%$ in Musa AAA, Musa AAB and Musa ABB, respectively. The amylose content in Musa ABB was highest (24.11\%), whilst in Musa AAA and Musa AAB were 17.65 and 19.42\%, respectively.

Table 2 shows the resistant starch, non-resistant starch, total starch and amylose content of whole seeds of cowpeas, red bean, red kidney bean and mung bean. The red bean seeds had highest level of resistant starch $(10.63 \%)$, whereas the lowest amount was found in the 
mung bean $(2.33 \%)$. When the non-RS content of cowpeas and beans was compared, it was found that beans had a lower amount of starch content (23.40$29.52 \%$ ) than that of cowpeas, ranging between 41.73 and $48.19 \%$. The highest value of total starch content, estimated from the sum of resistant starch and solubilized starch, was observed in the black/white speck cowpea $(56.37 \%$ ) whilst the others ranged from $25.73 \%$ in mung bean to $49.58 \%$ in white cowpea. The amylose contents of the legume seeds were high varying between $22.15 \%$ (black cowpea) to $34.85 \%$ (red kidney bean).

The red cowpea seeds had the highest level of resistant starch $(10.63 \%)$ whereas the lowest amount was found in black cowpea $(4.59 \%)$. When only the RS contents of cowpeas and beans were compared, it was found that beans had lower amount of solubilized starch (non-resistant starch) content (23.40-29.52\%) than that of cowpeas, ranged between 41.73 and $48.19 \%$. The highest value of total starch content, estimated from the sum of resistant starch and solubilized starch, was observed in the black/white speck cowpea (56.37\%) whilst the other were ranged from $25.73 \%$ in mung bean to $49.58 \%$ in white cowpea. The amylose contents of legume seeds were high varied between $22.15 \%$ (black cowpea) to $34.85 \%$ (red kidney bean).

\section{DISCUSSION}

Food compositions determined in this study, when compared between groups of starchy food plants, had significant variations in moisture contents, crude fat, ash, available carbohydrate, crude fiber, crude protein and starch compositions. However, it might be complicated to compare chemical compositions with all other studies because several factors can affect these compositions such as cultivar, growing and postharvest management and processing conditions. In cereals, brown rice presented the higher contents of protein, fat, ash and fiber than milled rice (KDML 105) due to bran removal. These values were similar to those reported by Champagne et al. (2004) and Moongngarm and Saetung (2010).

All legume seeds had higher levels of protein and contained lower amounts of carbohydrates than other starchy food plants. These observations are in agreement with previous reports of (Olapade et al., 2012). Among the roots and tubers, lesser yam had the highest protein and RS content. Nevertheless, when the RS values of all samples were compared, green banana fruits contained the highest amount of RS. These results were closed to the previous study of Tribess et al. (2009).

Table 1. Major chemical compositions of twenty-two starchy foods $(\mathrm{g} / 100 \mathrm{~g})$

\begin{tabular}{|c|c|c|c|c|c|c|}
\hline Food plants & Moisture & Protein & Fat & Ash & Fiber & Carbohydrate \\
\hline \multicolumn{7}{|l|}{ Cereals } \\
\hline Waxy rice (RD6) & $8.64 \pm 0.71^{b}$ & $6.78 \pm 0.38^{c}$ & $1.85 \pm 0.15^{\mathrm{c}}$ & $1.51 \pm 0.11^{\mathrm{b}}$ & $0.40 \pm 0.02^{\mathrm{cd}}$ & $80.82 \pm 1.3^{\mathrm{a}}$ \\
\hline Lueng 11 & $8.80 \pm 0.63^{\mathrm{ab}}$ & $7.15 \pm 0.55^{\mathrm{c}}$ & $1.27 \pm 0.19^{\mathrm{d}}$ & $1.22 \pm 0.07^{\mathrm{b}}$ & $0.67 \pm 0.03^{\mathrm{c}}$ & $80.89 \pm 2.45^{\mathrm{a}}$ \\
\hline KDML (milled rice) & $8.02 \pm 0.19^{c}$ & $6.91 \pm 0.29^{c}$ & $1.46 \pm 0.06^{\mathrm{d}}$ & $1.41 \pm 0.21^{\mathrm{b}}$ & $0.56 \pm 0.06^{\mathrm{c}}$ & $81.64 \pm 2.66^{\mathrm{a}}$ \\
\hline Khao Ta Hang & $8.45 \pm 0.32^{b}$ & $7.23 \pm 0.85^{\mathrm{c}}$ & $1.79 \pm 0.08^{c}$ & $1.46 \pm 0.06^{\mathrm{b}}$ & $0.88 \pm 0.11^{\mathrm{cb}}$ & $80.20 \pm 3.12^{\mathrm{a}}$ \\
\hline KDML (brown rice) & $9.44 \pm 0.69^{\mathrm{a}}$ & $8.87 \pm 0.06^{\mathrm{b}}$ & $2.92 \pm 0.03^{b}$ & $2.12 \pm 0.34^{\mathrm{a}}$ & $1.91 \pm 0.18^{\mathrm{b}}$ & $74.74 \pm 1.02^{\mathrm{b}}$ \\
\hline Corn (super sweet) & $7.94 \pm 0.54^{\mathrm{c}}$ & $11.36 \pm 0.02^{\mathrm{a}}$ & $5.47 \pm 0.19^{\mathrm{a}}$ & $2.36 \pm 0.53^{\mathrm{a}}$ & $8.49 \pm 0.65^{\mathrm{a}}$ & $64.38 \pm 2.34^{\mathrm{c}}$ \\
\hline \multicolumn{7}{|l|}{ Roots/Tubers } \\
\hline Sweet potato & $8.42 \pm 0.31^{\mathrm{ab}}$ & $3.40 \pm 0.73^{c}$ & $0.14 \pm 0.05^{\mathrm{b}}$ & $2.78 \pm 0.05^{\mathrm{a}}$ & $2.12 \pm 0.61^{\mathrm{b}}$ & $82.15 \pm 2.68^{b}$ \\
\hline Lesser yam & $7.44 \pm 0.61^{c}$ & $10.94 \pm 0.20^{\mathrm{a}}$ & $0.24 \pm 0.21^{\mathrm{b}}$ & $2.12 \pm 0.08^{b}$ & $1.81 \pm 0.04^{\mathrm{bc}}$ & $79.30 \pm 3.43^{b}$ \\
\hline White yam & $7.67 \pm 0.46^{\mathrm{c}}$ & $6.10 \pm 0.58^{b}$ & $0.28 \pm 0.01^{\mathrm{b}}$ & $3.14 \pm 0.22^{\mathrm{a}}$ & $1.75 \pm 0.29^{c}$ & $81.06 \pm 3.17^{\mathrm{b}}$ \\
\hline Yam bean & $9.10 \pm 0.68^{\mathrm{a}}$ & $1.23 \pm 0.02^{\mathrm{d}}$ & $1.17 \pm 0.04^{\mathrm{a}}$ & $1.24 \pm 0.03^{\mathrm{c}}$ & $10.94 \pm 0.02^{\mathrm{a}}$ & $76.32 \pm 4.1^{\mathrm{c}}$ \\
\hline Taro & $8.81 \pm 0.52^{\mathrm{a}}$ & $6.12 \pm 0.01^{\mathrm{b}}$ & $0.37 \pm 0.03^{b}$ & $2.71 \pm 0.31^{\mathrm{a}}$ & $2.25 \pm 0.31^{\mathrm{b}}$ & $79.74 \pm 2.22^{b}$ \\
\hline Cassava root & $7.61 \pm 0.78^{c}$ & $1.50 \pm 0.03^{\mathrm{d}}$ & $0.48 \pm 0.06^{\mathrm{b}}$ & $1.87 \pm 0.42^{b}$ & $1.33 \pm 0.18^{\mathrm{d}}$ & $87.21 \pm 3.95^{\mathrm{a}}$ \\
\hline \multicolumn{7}{|l|}{ Bananas } \\
\hline Musa ABB group & $7.77 \pm 0.21$ & $4.01 \pm 0.29$ & $0.24 \pm 0.02$ & $4.61 \pm 0.17$ & $8.82 \pm 0.25^{\mathrm{a}}$ & $74.56 \pm 3.11^{\mathrm{b}}$ \\
\hline Musa AAB group & $7.13 \pm 0.67$ & $4.98 \pm 0.14$ & $0.42 \pm 0.03$ & $4.49 \pm 0.28$ & $5.11 \pm 0.51^{\mathrm{b}}$ & $77.87 \pm 2.74^{\mathrm{ab}}$ \\
\hline Musa AAA group & $7.06 \pm 0.44$ & $3.97 \pm 0.35$ & $0.34 \pm 0.07$ & $3.67 \pm 0.44$ & $6.03 \pm 0.73^{b}$ & $78.93 \pm 1.83^{\mathrm{a}}$ \\
\hline \multicolumn{7}{|l|}{ Legumes } \\
\hline Black cowpea & $7.88 \pm 0.23^{b}$ & $20.78 \pm 2.22^{c}$ & $1.54 \pm 0.13^{\mathrm{b}}$ & $4.06 \pm 0.13^{\mathrm{a}}$ & $1.48 \pm 0.43^{\mathrm{b}}$ & $64.26 \pm 1.20^{\mathrm{a}}$ \\
\hline White cowpea & $8.92 \pm 0.74^{\mathrm{ab}}$ & $22.34 \pm 4.50^{\mathrm{bc}}$ & $2.08 \pm 0.81^{\mathrm{a}}$ & $4.23 \pm 0.11^{\mathrm{a}}$ & $1.88 \pm 0.08^{\mathrm{ab}}$ & $60.55 \pm 3.11^{\mathrm{bc}}$ \\
\hline $\begin{array}{l}\text { Black / white } \\
\text { speckled cowpea }\end{array}$ & $7.81 \pm 0.62^{b}$ & $27.22 \pm 1.23^{\mathrm{a}}$ & $1.36 \pm 0.41^{b}$ & $4.00 \pm 0.05^{\mathrm{a}}$ & $1.42 \pm 0.17^{\mathrm{b}}$ & $58.19 \pm 2.03^{c}$ \\
\hline Red cowpea & $9.94 \pm 0.86^{\mathrm{a}}$ & $21.66 \pm 1.62^{\mathrm{c}}$ & $0.63 \pm 0.02^{\mathrm{c}}$ & $4.09 \pm 0.26^{\mathrm{a}}$ & $1.39 \pm 0.02^{\mathrm{c}}$ & $62.29 \pm 3.06^{\mathrm{ab}}$ \\
\hline Red kidney bean & $9.39 \pm 0.20^{\mathrm{a}}$ & $23.83 \pm 1.48^{b c}$ & $1.50 \pm 0.93^{\mathrm{b}}$ & $3.85 \pm 0.12^{\mathrm{ab}}$ & $1.29 \pm 0.03^{b}$ & $60.14 \pm 2.28^{b c}$ \\
\hline Mung bean & $7.91 \pm 0.55^{\mathrm{b}}$ & $24.08 \pm 0.08^{\mathrm{b}}$ & $1.55 \pm 0.06^{\mathrm{b}}$ & $2.87 \pm 0.4^{\mathrm{c}}$ & $2.20 \pm 0.05^{\mathrm{a}}$ & $61.39 \pm 2.74^{\mathrm{b}}$ \\
\hline
\end{tabular}

a,b,c.: Means within columns followed by the same letter are not significant different at $\mathrm{p}<0.05$ 
Table 2. Starch compositions of cereals, roots/tubers, green bananas and legume seeds $(\mathrm{g} / 100 \mathrm{~g})$

\begin{tabular}{|c|c|c|c|c|}
\hline Food Plants & Resistant Starch & Non-Resistant Starch & Total Starch & Amylose \\
\hline \multicolumn{5}{|l|}{ Cereals } \\
\hline Waxy rice & $2.72 \pm 0.19^{b}$ & $72.04 \pm 4.06^{\mathrm{a}}$ & $74.76 \pm 2.19^{\mathrm{a}}$ & $2.13 \pm 0.08^{\mathrm{d}}$ \\
\hline Lueng 11 & $4.41 \pm 0.92^{\mathrm{a}}$ & $64.16 \pm 4.63^{\text {ba }}$ & $68.57 \pm 5.65^{\mathrm{a}}$ & $29.67 \pm 1.54^{\mathrm{a}}$ \\
\hline KDML milled rice & $2.15 \pm 0.66^{\mathrm{b}}$ & $71.63 \pm 3.01^{\mathrm{a}}$ & $73.78 \pm 2.76^{\mathrm{a}}$ & $18.91 \pm 0.73^{\mathrm{c}}$ \\
\hline KDML brown rice & $2.67 \pm 0.51^{b}$ & $71.29 \pm 4.52^{\mathrm{a}}$ & $73.96 \pm 3.44^{\mathrm{a}}$ & $17.84 \pm 0.92^{\mathrm{c}}$ \\
\hline Khao Ta Hang & $4.85 \pm 0.18^{\mathrm{a}}$ & $64.66 \pm 1.46^{\mathrm{b}}$ & $69.51 \pm 2.65^{\mathrm{a}}$ & $25.62 \pm 1.02^{\mathrm{b}}$ \\
\hline Corn (sweet corn) & $1.16 \pm 0.74^{\mathrm{c}}$ & $35.07 \pm 2.95^{\mathrm{c}}$ & $36.23 \pm 1.47^{b}$ & $19.54 \pm 0.81^{\mathrm{c}}$ \\
\hline \multicolumn{5}{|l|}{ Roots/Tubers } \\
\hline Sweet potato & $3.19 \pm 0.56^{\mathrm{d}}$ & $49.35 \pm 3.65^{\mathrm{b}}$ & $52.54 \pm 2.72^{\mathrm{c}}$ & $28.05 \pm 0.85^{\mathrm{a}}$ \\
\hline Lesser yam & $23.25 \pm 2.78^{\mathrm{a}}$ & $19.46 \pm 0.88^{c}$ & $54.70 \pm 2.49^{\mathrm{bc}}$ & $26.20 \pm 1.73^{\mathrm{a}}$ \\
\hline White yam & $4.30 \pm 0.42^{\mathrm{c}}$ & $53.72 \pm 2.89^{\mathrm{ab}}$ & $58.02 \pm 1.96^{\mathrm{b}}$ & $17.32 \pm 0.21^{\mathrm{c}}$ \\
\hline Yam bean & $3.69 \pm 0.41^{\mathrm{cd}}$ & $20.27 \pm 2.90^{c}$ & $23.96 \pm 1.31$ & $11.45 \pm 0.17^{\mathrm{d}}$ \\
\hline Taro & $4.12 \pm 0.29^{\mathrm{c}}$ & $59.61 \pm 4.71^{\mathrm{a}}$ & $63.74 \pm 5.21^{\mathrm{a}}$ & $16.84 \pm 1.11^{\mathrm{c}}$ \\
\hline Cassava & $9.69 \pm 1.28^{\mathrm{b}}$ & $55.99 \pm 4.92^{\mathrm{a}}$ & $65.71 \pm 1.79^{\mathrm{a}}$ & $23.81 \pm 0.78^{b}$ \\
\hline \multicolumn{5}{|l|}{ Green Bananas } \\
\hline Kluai Nam Wa (ABB) & $45.87 \pm 2.73^{\mathrm{a}}$ & $21.03 \pm 0.35^{b}$ & $66.90 \pm 4.88^{\mathrm{ab}}$ & $24.11 \pm 0.36^{\mathrm{a}}$ \\
\hline Kluai Khai (AAB) & $35.14 \pm 2.41^{\mathrm{b}}$ & $31.99 \pm 2.04^{\mathrm{a}}$ & $67.45 \pm 1.33^{\mathrm{a}}$ & $19.42 \pm 0.78^{b}$ \\
\hline Kluai Hom (AAA) & $43.38 \pm 3.26^{\mathrm{a}}$ & $19.38 \pm 0.82^{c}$ & $62.77 \pm 3.16^{\mathrm{b}}$ & $17.65 \pm 0.54^{b}$ \\
\hline \multicolumn{5}{|l|}{ Legumes } \\
\hline Black cowpea & $4.59 \pm 0.23^{\mathrm{d}}$ & $44.28 \pm 2.14^{\mathrm{a}}$ & $48.87 \pm 2.65^{b}$ & $22.15 \pm 1.13^{d}$ \\
\hline White cowpea & $7.84 \pm 0.55^{\mathrm{c}}$ & $41.73 \pm 1.87^{\mathrm{ab}}$ & $49.58 \pm 3.17^{\mathrm{ab}}$ & $27.01 \pm 0.84^{\mathrm{c}}$ \\
\hline Black/white speckled cowpea & $8.18 \pm 0.31^{\mathrm{c}}$ & $48.19 \pm 2.02^{\mathrm{a}}$ & $56.37 \pm 3.94^{\mathrm{a}}$ & $26.93 \pm 0.91^{\mathrm{c}}$ \\
\hline Red bean & $10.63 \pm 0.16^{\mathrm{a}}$ & $29.52 \pm 1.45^{\mathrm{c}}$ & $40.15 \pm 2.06^{\mathrm{c}}$ & $30.47 \pm 1.07^{b}$ \\
\hline Red kidney bean & $9.54 \pm 0.11^{\mathrm{b}}$ & $24.54 \pm 1.63^{\mathrm{d}}$ & $34.10 \pm 2.12^{\mathrm{d}}$ & $34.85 \pm 1.24^{\mathrm{a}}$ \\
\hline Mung bean & $2.33 \pm 0.04^{\mathrm{e}}$ & $23.40 \pm 1.31^{\mathrm{d}}$ & $25.73 \pm 0.88^{\mathrm{e}}$ & $31.21 \pm 0.98^{\mathrm{b}}$ \\
\hline
\end{tabular}

\section{CONCLUSION}

In conclusions, the carbohydrate was the major composition of all foods in this study. The legume seeds and lesser yam had a high concentration of protein and moderate amount of RS, whereas green bananas had highest amount of RS. The study implied that these three food plants could be a source of RS and could have commercial possibilities of their own or as a base with other foods. However, much investigation is still required to fully understand the application of these raw materials as natural RS sources, particularly the stability of RS during processing to be a food product. Moreover, the basic knowledge gained from this study would be useful information to design and develop new food based products. The data about RS content in food plants could be applied to estimate the intake of RS in Thai and other consumer diets.

\section{ACKNOWLEDGEMENT}

The researcher gratefully acknowledge the Division of Research Facilitation and Dissemination, Mahasarakham University for the financial supports.

\section{REFERENCES}

Aparicio-Saguilan, A., S.G. Sayago-Ayerdi, A. VargasTorres, J. Tovar and T.E. Ascencio-Otero et al., 2007. Slowly digestible cookies prepared from resistant starch-rich lintnerized banana starch. J. Food Comp. Anal., 20: 175-180. DOI: 10.1016/j.jfca.2006.07.005

Champagne, E.T., Delilah F. Wood, Bienvenido O. Juliano and Donald B. Bechtel, 2004. The Rice Grain and its Gross Composition. In: Rice: Chemistry and Technology, Champagne E.T. (Ed.), AACC, St Paul, MN, USA., ISBN-10: 1891127349.

Elmsthl, H.L., 2002. Resistant starch_content in a selection of starchy foods on the Swedish market. Eur. J. Clin. Nutr., 56: 500-505. PMID: 12032648

Fuentes-Zaragoza, E., M.J. Riquelme-Navarrete, E. Sanchez-Zapata and J.A. Perez-Alvarez, 2010. Resistant starch as functional ingredient: A review. Food Res. Int., 43: 931-942. DOI: 10.1016/j.foodres.2010.02.004

Hasler, C.M. and A.C. Brown, 2009. Position of the American dietetic association: Functional foods. J. Am. Dietetic Assoc., 109: 735-746. DOI: 10.1016/j.jada.2009.02.023 
Howell, T.A. and R.R. Cogburn, 2004. Rough Rice Storage. In: Rice: Chemistry and Technology, Champagne E.T. (Ed.), AACC, St Paul, MN, USA., ISBN-10: 1891127349, pp: 269-282.

Moongngarm, A. and N. Saetung, 2010. Comparison of chemical compositions and bioactive compounds of germinated rough rice and brown rice. Food Chem., 122: $782-788$.

DOI: 10.1016/j.foodchem.2010.03.053

Morrison, W.R. and B. Laignelet, 1983. An improved colorimetric procedure for determining apparent and total amylose in cereal and other starches. J. Cereal Sci., 1: 9-20. DOI: 10.1016/S0733-5210(83)80004-6

Nugent, A.P., 2005. Health properties of resistant starch. Nutr. Bull., 30: 27-54. DOI: 10.1111/j.14673010.2005.00481.x

Olapade, A.A., O.B. Oluwole and O.C. Aworh, 2012. Physico-chemical properties and consumer acceptance of instant cowpea (Vigna unguiculata) powder for complementary food. African J. Food Sci. Technol., 3: 102-106.

Ovando-Martinez, M., S. Sayago-Ayerdi, E. AgamaAcevedo, I. Goni and L.A. Bello-Perez, 2009. Unripe banana flour as an ingredient to increase the undigestible carbohydrates of pasta. Food Chem., 113: 121-126. DOI: 10.1016/j.foodchem.2008.07.035
Sanz, T., A. Salvador, R. Baixauli and S.M. Fiszman, 2009. Evaluation of four types of resistant starch in muffins. II. Effects in texture, colour and consumer response. Eur. Food Res. Technol., 229: 197-204. DOI: $10.1007 / \mathrm{s} 00217-009-1040-1$

Tribess, T.B., J.P. Hernandez-Uribe, M.G.C. MendezMontealvo, E.W. Menezes and L.A. Bello-Perez et al., 2009. Thermal properties and resistant starch content of green banana flour (Musa cavendishii) produced at different drying conditions. LWT-Food Sci. Technol., 42: 1022-1025. DOI: 10.1016/j.lwt.2008.12.017

Wang, Y., M. Zhang and A.S. Mujumdar, 2012. Influence of green banana flour substitution for cassava starch on the nutrition, color, texture and sensory quality in two types of snacks. LWT-Food Sci. Technol., 47: 175-182. DOI: 10.1016/j.lwt.2011.12.011

Williams, S., 1984. Official Methods of Analysis of the Association of Official Analytical Chemists. 14th Edn., AOAC, Arlington, Va., ISBN-10: 0935584242, pp: 1141. 